\title{
Awaken Spirit Life by Sharing Life Struggles: A Critical Discourse Analysis of Muniba Mazari's Speech
}

\author{
Ernawati $^{1 *}$ and Airyn Eki Shandy ${ }^{2}$ \\ ${ }^{1,2}$ Post Graduate program of English Language Education, Universitas Muhammadiyah Parepare, Indonesia \\ *erna28761@gmail.com
}

\begin{abstract}
The Critical Discourse Analysis is often applied to analyze public speech such as motivation speech, in which the speaker to interest, motivate and give an inspirational response from the audience. This study presents a critical discourse analysis of Muniba Mazari's speech (limited to one speech about her life struggle in her own words at TEDx) to reveal the concept of empowering women by sharing life's struggles in the socio-cultural context of Pakistan. based on Critical Discourse Analysis Theory and Systematic Functional Linguistics, analyze Muniba Mazari's motivational speech from the point of view of the language used to inspire listeners, word choice, and expression (body language) in her speech while sharing her life struggles. This study uses a critical discourse analysis method, the linguistic elements used to inspire listeners through the choice of words, and expressions (body language) by Muniba Mazari in his speech when sharing his life struggles to awaken the spirit of life. The result shows In a speech the researcher found that the speaker took pauses in speaking, the rhythm was slow, steady and several times made deliberate pauses during speaking, besides that the researcher also found repetition and emphasis on words that were considered important and the speaker told stories of his life struggles
\end{abstract}

Key words: Critical Discourse Analysis, motivational speech, Systematic Functional Linguistics, Muniba Mazari.

\section{Introduction}

Muniba Mazari, who was born on 3rd March 1987, belonging to the Baloch background, also known as the Iron Lady of Pakistan she is a Pakistani artist, model, activist, motivational speaker, singer, social reformer and television host. She became the National Ambassador for UN Women Pakistan after being shortlisted in the 100 Inspirational Women of 2015 by BBC [1]. She also made it to the Forbes 30 under 30 lists for 2016. before becoming paralyzed Muniba went to the Army Public School, and later attended his hometown for the BFA. At the age of 18, before he could finish his studies, he was already married. In 2008, he was involved in an accident, which left him paralyzed. at that time Muniba and her husband were travelling from Quetta to Rahim Yar Khan. Their car was in an accident, in which she suffered several major injuries, including fractures in her arm (radius and ulna), ribs, shoulder blades, collarbone and spine. His lungs and heart were also severely cut. In addition, his entire lower body became paralysed. He was taken to a nearby hospital, which did not have adequate equipment to treat such a severe case. He was then 
transferred to a hospital in Rahim Yar Khan, and finally, he was admitted to Agha Khan Hospital, Karachi. After the operation, he was left bedridden for two years. Physiotherapy was started, which helped him recover enough to use a wheelchair [2]. She uses a wheelchair at the age of 21 which makes her Pakistan's first wheelchair-using model. Also serving as the National Ambassador for UN Women Pakistan [3].

In addition, Muniba was chosen by Pond's as Pond's Miracle Woman. She was also chosen by the international hairdressing salon, Toni \& Guy, to be the first wheelchair user model in Asia. Her first campaign for them was called Women of Substance [2]. Muniba Mazari has been part of the Dil Say Pakistan campaign to spread a sense of patriotism and unity in Pakistan. She has performed as a singer for them, including a YouTube video published in August 2017 as part of their Independence Day campaign for that year as a motivational speaker.

Muniba has participated as a motivational speaker in various fields, with his first break being TED Talks, Islamabad. Some of his notable works as a speaker include Entrepreneurs' Organization Network, Pakistan, Motivational speech at Army Public School, Peshawar and Combined Military Hospital, Peshawar [2]. She also sang Ye Watan Tumhara Hai by Mehdi Hassan[2], Leader's Summit[2], Motivational speech at Bank Alfalah Training Centre, Lahore[2], Invited as a guest to Women Entrepreneurship Day at the National University of Science and Technology Business School [2], Talked about social entrepreneurship at the Youth Alumni Reunion 2014[2], Young Presidents' Organization (YPO)[5], VCon Malaysia[5], Vcon Dubai[5]. Communication is an important aspect of daily activities. It is the way people communicate with others in society. By communicating, people can convey information or ideas. Communication is the behaviour of individuals in sending and receiving information [6]. Meanwhile, another perspective said that communication plays an important role in the life of everyone in the world to convey and provide information [7]. In communication, people have an intention or purpose when they speak. Of course, in communicating, language is needed, both spoken and written to convey messages. As defined, language can transfer ideas, thoughts, desires, and emotions to others [8]. In linguistics, discourse refers to a unit of language longer than a single sentence. The word discourse is derived from the Latin prefix dis- meaning "away" and the root word currere meaning "to run". Discourse, therefore, translates to "run away" and refers to the way that conversations flow. To study discourse is to analyze the use of spoken or written language in a social context.

Discourse is generally defined as everything beyond the sentence [9]. Another definition of discourse says that it is a series of languages or speech that forms meaning and it cannot be separated from the context and situation [10]; it means that the context cannot be released in understanding a discourse. Discourse is not only in the form of text because discourse can also be in the form of signs, or symbols that are meaningful in the language [10]. Thus, it can be in the form of traffic signs, trumpet sounds, or pictures that the meaning is understood along with the context.

Critical Discourse Analysis (CDA) is a type of discourse analytical research that primarily studies the way social power abuse, dominance, and inequality are enacted, reproduced, and resisted by text and talk in the social and political context. With such dissident research, critical discourse analysts take an explicit position, and thus want to understand, expose, and ultimately resist social equality [11]. CDA refers to the ways of understanding the social world drawn by critical theory [12].

The object of CDA is public speech, such as advertisement, newspaper, political propaganda, official documents, laws and regulations and so on. Its aim is to explore the relationships among language, ideology and power.

Currently, the development of Critical Discourse Analysis has reached a new stage. We can see more and more articles on Critical Discourse Analysis appearing in academic journals. In this modern era, there are many videos that we often encounter on YouTube, TV and others. one of speeches that we often see is a motivational speech. Each motivator has the characteristics, style, and strength of language in giving influence/inspiration to listeners. The study of motivational speech has attracted many people's attention as an inspiration in advancing their lives for the better, not only among political scientists and historians but also attracts the attention of linguists. both young and old.

In this article, the author will apply Hallidays Systemic Functional Grammar, in terms of the three metafunctions: ideational function, interpersonal function and textual function, to find out the formal features of Muniba Mazari's speeches. Its aim is to explore the relationships among language, ideology and power and to find out how to use the power of speeches to persuade the public to accept and give motivation to another. how the speaker told stories of his life struggles to Awaken Spirit Life another.

\section{Theoretical Reviews}

\section{Advantages and Disadvantages of Textbook}

M.A.K. Hallidays Systemic Functional Grammar is usually considered the main foundation of Critical Discourse Analysis as well as other theories in pragmatics. Systemic Functional Grammar has two components: SYSTEMIC GRAMMAR and FUNCTIONAL GRAMMAR They are two inseparable parts for an integrated framework of linguistic theory. "Systemic grammar aims to explain the internal relations in language as a system network or meaning potential. And this network consists of subsystems from which language users make choices. Functional grammar 
aims to reveal that language is a means of social interaction, based on the position that language system and the forms that make it up are inescapably determined by the uses or functions which they serve" [13].

Halliday thinks the procedure of stylistic analysis can be divided into three logically ordered phrases: Analysis, Interpretation and Evaluation. The limitless practical functions can be generalized into a set of highly coded and abstract functions-meta-functions, which are inherent in every language. His idea of meta-function includes the ideational function, the interpersonal function and the textual function.

Speech acts are part of linguistics that discuss language. [14] states that a speech act is an act that refers to the action of making an utterance. The speech act is used to express meaning and a word that expresses a purpose. [15] states that speech acts are an action performed via utterance. The speech acts are generally taken to conclude action such as greeting, ordering, promising, inviting, warning, thanking, saying goodbye, etc. This study uses the theory [16] to identify kinds of speech acts. There are five kinds of the illocutionary act [17], as follows:

Representatives. Representatives are kinds of illocutionary what speakers believe about truth or not. Representatives tell about the truthfulness of the utterance. This type acts such as: stating, describing, affirming, boasting, concluding, claiming, etc [17].

Directives. Directives is the utterances to attempt by the speaker to the hearer to do something [17]. Directives perform such as commanding, ordering, requesting, warning, suggesting, inviting, etc.

Commissives. Commisives are a kind of illocutionary acts that the intention of the speakers to promise of offering something [17]. In other words, commissives are the utterance produces to give action in the future. They are promising, vowing, planning, threatening, offering, etc.

Declaratives. Declaratives have a specific use of the place and the event [17]. Declaratives can change a particular situation instantly. The types such as declare, announce, curse, define, nominate, etc.

Expressives. Expressives are the intention of the speaker feeling through the psychological attitude. Expressives tell about the speaker's feelings expression such as sorrow, apology, thank, greet, pleasure, like, dislike, joying, etc [17].

Perlocutionary act. Perlocutionary acts are performing the listener after hearing the utterance of the speakers. The perlocutionary act is the performance of the listener, they are persuading, deterring, or inspiring [17].

\section{Methodology}

His study uses a critical discourse analysis method, which refers to the Teun A. van Dijk analysis method. Concerning the three dimensions of analysis previously discussed, that are text, social cognition and social context. by presenting the motivational life based on Muniba Mazari's speech and her story lif to awaken spirit life another people. The data collection technique in this study was through watching videos of Muniba Mazari's speeches obtained from the internet (youtube). In this study, only one speech of Muniba Mazari was analyzed because this speech went viral on all social media. According to the YouTube trending list, this speech was watched at number one trending in August 2017. This speech was delivered at TEDx which was held in Malaysia in 2017. below is Muniba Mazari full TRANSCRIPT on video:

"Thank you so much for all the love, for all the warmth. Thank you all for accepting me. Thank you very much."

Well, I always start my talk with some disclaimer. And that disclaimer is that I never claimed to be a motivational speaker. Yes, I do speak. But I feel like a storyteller. Because where ever I go I share a story with everyone.

I believe in the power of words. Many people speak before they think. But I know the value of words. Words can make you, break you, they can heal your soul, they can damage you forever. So, I always try to use positive words in my life. Wherever I go, they call it adversity, I call it opportunity. They call it a weakness, I call it strength. They call me to disable, I call myself differently able. They see my disability. They see my disability. I see my ability. There are some incidents that happened in your life. And those incidents are so strong that they change your DNA. Those incidents and accidents are so strong that they break you physically. They deform your body but they transform your soul. Those incidents break you, deform you but they mould you into the best version of you. And the same thing happened to me. And I am going to share what exactly happened to me.[18 ]

The analysis on the textual dimension of the speech focused on intonation, repetition and emphasis of words, body language, expressions, and stories. Muniba Mazari's life struggle that can motivate listeners. 


\section{Findings and Discussion}

After observing through watching videos from youtube. research finds motivational speech data that In the speech the researcher found that the speaker took a break in speech, slow, steady rhythm and several times made deliberate pauses during speaking, besides that the researcher also found repetition and emphasis on words which were considered as important points. From the video, the researcher also found that in addition to the spoken language used by Muniba Mazari, the body was also carried out to support the speech movements conveyed such as confident hand movements. Besides that, crescendo increases the tempo and volume so that it gives enthusiasm, motivation and inspiration to listeners. even the speaker sheds tears in his speech so that it makes listeners feel touched as if they also feel what the speaker is conveying.

Muniba Mazari in a speech said "that if you think that your life is hard and you are giving up on that when you think that way you are being unfair to your own self its the story of a woman who made people realize that sometimes problems is not too big we are too small because we cannot handle them" does she think that people who think that life is difficult and resign themselves to their circumstances are people who are unfair to themselves itself is not a difficult life but we sometimes choose not to fight/give up. Muniba Mazari in his speech taught how she faced this life by always thinking positively and making every life an opportunity without thinking about other people's opinions of us. as he made every trial an opportunity as quoted from his speech "so I always use the positive words in my life wherever I go they call it adversity, I call it opportunity the call it weakness I call it strength they call me disabled I call myself differently-abled"

\section{Conclusion}

The results of this study reveal something different from previous studies. In addition, the new thing that appears is the focus of research that critically reveals how expressions greatly affect the listener in delivering a speech and the importance of setting a slow, steady rhythm and making pauses during speaking, in addition, the researcher also repeats and emphasizes words that are considered as important point like(19) there are ten types of discourse markers, five of which are linking adverbials, answer forms, stance adverbials, answer elicitors, and interjections. and this research also considers the life story of someone who is dark can be used as encouragement, motivation and perspective on life for others that a difficult life is not something we should be afraid of but about how we have to fight.

On the basis of the above discussion, we may come to the conclusion. Systemic Functional Grammar, we can summarize the features of Muniba Mazari's speeches as follow. she used more simple words and short sentences instead of difficult ones. His language is easy and colloquial [20].

\section{Acknowledgements}

Praise and gratitude I pray to the presence of Allah SWT who has given the opportunity and health so that this article can be completed and I also thank the supervisors who constantly guide, direct and provide positive and constructive suggestions. friends who always support me so that this article can be finished.

\section{References}

[1] Dikhawa. (2017, Nov.30) Muniba Mazari - The Iron Lady of Pakistan is a True Inspiration [Online]. Available: https://dikhawa.pk/blogs/content/muniba-mazari-the-iron-lady-of-pakistan-is-a-true-inspiration

[2] M. Tarar. Do we not bleed?: Reflections of a 21st-century Pakistani. India: Aleph Book Companies, 2018.

[3] S. Shahzadi, M. Hanif, and H. Imtiaz, "Empowering Women by sharing life struggles: A Critical Discourse Analysis of Muniba Mazari's inspirational speech.", IJWE, vol. 4, pp. 14-17, Dec. 2018.

[4] The Muslim 500. (2021). Muniba Mazari [Online]. Available: https://themuslim500.com/social-issues/

[5] K. Bach, Speech Ats And Pragmatics. Cambridge: Blackwell Press, 2006.

[6] Nurjannah, Effective Interpersonal Communication Used by Tour Guides at Fort Rotterdam Makassar: State Islamic University, 2017

[7] A. Chaer, and L. Agustina, Sosiolinguistik Perkenalan Awal. Jakarta: Rineka Cipta, 2010.

[8] D. Schiffrin, D. Tannen, and H. E. Hamilton. The Handbook of Discourse Analysis. Hong Kong: Blackwell Publishers, 2001. 
[9] Y. A. Darma, Analisis wacana kritis. Bandung: Yrama Widya, 2009.

[10] Van Dijk, "A Handbook of Discourse Analysis" London Academic Press Limited, Vol 4, 1985.

[11] M. A. K. Halliday, Linguistic function and literary style: an inquiry into the language of William Goldings The

[12] Hu Zhuanglin, A Course of Linguistics. Peking: Peking University Press, 1988.

[13] G. Yule, Pragmatics. Hong Kong: Oxford University Press, 1996

[14] J. R. Searle, Speech Acts (An essay in the philosophy of language) Expressions, meaning, and speech acts. Cambridge: Cambridge University Press, 1969.

[15] J. R. Austin, Speech acts An Essay In The Philosophy Of Language. New York: Cambridge University Press, 1969.

[16] J. R. Searle, Expression and Meaning Studies in The Theory Of Speech Acts. United States: Cambridge University Press, 1979.

[17] English Speeches. Muniba Mazari Speech: We all are Perfectly Imperfect [Online]. Available: https://www. englishspeecheschannel.com/english-speeches/muniba-mazari-speech/

[18] TEDx Malaysia Youtube. (2017). Mazari, Muniba [Online]. Available: https://www.youtube.com/watch?v= fBnAMUkNM2k\&t//

[19] S. Suprihatiningsih, C. Christina. "Discourse Markers in Muniba Mazari's "We All are Perfectly Imperfect" Speech (2017)". Metaphor, 3(2), 64-74. 2021. Available: https : //ojs . unsiq.ac.id/index.php/metaphor/ article/view/1947 